\title{
Hazelnut Pollination
}

\author{
J.L. O Isen, S.A. M ehlenbacher, and A.N . Azarenko
}

AdDITIONAL INDEX WORDS. Corylusavelana, flowering, production, orchard management, filbert, alleles

Summary. H azelnuts, (C orylus avellana L.), are wind-pollinated, monoecious, mostly dichoga mous, and self-incompatible. A bout $90 \%$ of the cultivars studied are protandrous. Anthesis of the pistillate flower is temperature-dependent and occurs December through February, peaking in January. Stigmatic surfaces may remain receptive for up to 3 months. Four to 5 months separate pollination and fertilization of the ovule; the latter usually occurring between mid-M ay and the end of June in 0 regon. A $10 \%$ pollinizer density has been the standard, with a recommended distance of $66 \mathrm{ft}(20 \mathrm{~m})$ or less between the main cultivar and the nearest pollinizer. Two or three different pollinizer cultivars, with different times of pollen shed, are recommended. The 0 regon hazelnut industry is presently combating the fungal disease, eastern filbert blight, caused by A nisogramma anomala (Peck). C urrent management recommendations suggest reducing risk of infection are to reduce the most susceptible pollinizer cultivars to a density $5 \%$, then gradually replace those left with immune or more resistant genotypes.

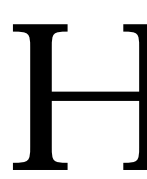

azelnut production in the U.S. is centered in O regon's Willamette Valley. There are nearly 30,000 acres $(12,141$ ha) of hazelnuts in 0 regon, representing about $5 \%$ of the world's production. Turkey produces around $70 \%$ followed by I taly at $20 \%$ with Spain and the U .S. contributing most of the remaining production.

$\mathrm{H}$ azelnuts are wind-pollinated, with pollen transfer taking place in the winter months. They are monoecious, and self-incompatible (Thompson, 1979a). The incompatibility is controlled by a single locus with multiple alleles and is a sporophytic type (Thompson, 1979b). The S-alleles of several cultivars were listed by Thompson (1979c), and M ehlenbacher and Thompson (1988). The 25 unique S-alleles have been identified in Corylusavellana L. (M ehlenbacher, 1997a).

All alleles identified to date are codominant in the pistil. They exhibit either dominance or codominance in the pollen ( $M$ ehlenbacher and Thompson, 1988). Scanning electron microscopy confirmed the stigmatic surface as the site of incompatibility (H ampson et al., 1993). I ncompatible pollinations are expressed as delayed or reduced germination, with distorted pollen tubes that fail to penetrate the stigma.

M ehlenbacher (1997b) used a fluorescence microscopy method to determine the compatibility of crosses within $24 \mathrm{~h}$, using female flowers from bagged branches and frozen pollen.

Stigmatic surfaces remain receptive for up to 3 months (Thompson, 1979b). A.N . Azarenko is currently investigating the biochemical, physiological and molecular aspects of sporophytic self-incompatibility. Two RAPD markers have been identified for the $S_{1}$ and $S_{2}$ alleles (Pomper et al., 1998).

O regon State U niversity, D epartment of H orticulture, 4017 Ag. \& Life Sci., Corvallis, OR 97331-7304.

The cost of publishing this paper was defrayed in part by the payment of page charges. U nder postal regulations, this paper therefore must be hereby marked advertisement solely to indicate this fact. 
T able 1. Compatibility of selected hazelnut pollinizers and cultivars.

\begin{tabular}{|c|c|c|c|c|c|c|c|c|c|c|c|c|c|c|c|c|}
\hline & \multirow[b]{2}{*}{ Pollen } & \multirow[b]{2}{*}{ Parent } & \multicolumn{13}{|c|}{ Cultivar ${ }^{2}$} & \multirow[b]{2}{*}{ OSU } \\
\hline & & & TG & $\mathbf{w}$ & VR 11 & B & $\mathbf{L}$ & VR 20 & $\mathrm{Ca}$ & $\mathrm{CI}$ & VR 23 & H G & G & $J$ & $\mathbf{E}$ & \\
\hline $\begin{array}{l}\text { Female } \\
\text { parent }\end{array}$ & \multicolumn{2}{|c|}{$\begin{array}{c}\text { Alleles } \\
\text { expressed }\end{array}$} & $2^{y}$ & 3 & 3 & 1 & 3,8 & 3 & 10,21 & 3 & 5,15 & 14 & 3 & 1 & 1 & \\
\hline TG & $2^{x}$ & 23 & $-w$ & $t^{v} m^{u}$ & $+m$ & $+\mathrm{m}$ & $+\mathrm{m}$ & +1 & + & $H$ & + & +1 & + & + & + & + \\
\hline$B$ & 1 & 2 & - & + & te & - & $+\mathrm{m}$ & $+m$ & +1 & +1 & +1 & $H$ & + & + & - & - \\
\hline W & 1 & 3 & te & - & - & - & - & - & $+m l$ & - & - & $+\mathrm{ml}$ & +1 & - & - & - \\
\hline$E$ & 1 & 11 & + & + & + & - & te & te & $+\mathrm{m}$ & $+m$ & $+\mathrm{m}$ & +1 & +1 & +1 & - & - \\
\hline $\mathrm{Ca}$ & 10 & 21 & + & + & + & + & + & + & - & $+m$ & $+\mathrm{m}$ & $+m$ & $+m$ & + & + & + \\
\hline $\mathrm{Cl}(\mathrm{OSU} 276.142)$ & 3 & 8 & + & - & - & + & - & - & + & - & - & te & + & - & + & + \\
\hline
\end{tabular}

zTG = 'Tonda di Giffoni', W = 'Willamette', VR11 =VR 11-27, B = 'Barcelona', L ='Lewis', VR20 =VR 20-11, Ca= 'Casina', Cl= 'Clark', VR23 =VR23-18, H G ='H all's Giant', $G={ }^{\prime} G e m ', J=$ Jemtegaard \#5', $E=$ 'Ennis', OSU = OSU 228.084.

YThe horizontal row found below the list of cultivars has the incompatibility alleles that are expressed in the pollen listed.

xT he (-) indicates an incompatible cross. It is preferable when identifying suitable pollinizers that the cross is compatible in both directions.

wA $(+)$ indicates that the cross is compatible.

vT he text found below the + indicates the time of pollen shed relative to the bloom of the female parent; $\mathrm{m}=\mathrm{mid}, \mathrm{e}=$ early, $\mathrm{I}=\mathrm{late}$.

un the vertical column, to the right of the female parent column, is the list of incompatible alleles that are expressed in the female flower.

T able 2. Compatibility of selected hazelnut pollinizers and cultivars.

\begin{tabular}{|c|c|c|c|c|c|c|c|c|c|c|c|c|c|c|c|}
\hline & & & \multicolumn{13}{|c|}{ C ultivar } \\
\hline & Pollen & Parent & B & $\mathrm{Ca}$ & $\mathbf{C I}$ & $\mathbf{E}$ & HG & $J$ & $\mathbf{L}$ & TG & $\mathbf{w}$ & VR 11 & VR 20 & VR 23 & OSU \\
\hline $\begin{array}{l}\text { Female } \\
\text { parent }\end{array}$ & \multicolumn{2}{|c|}{$\begin{array}{c}\text { Alleles } \\
\text { expressed }\end{array}$} & $1^{y}$ & 10,21 & 3,8 & 1 & 5,15 & 3 & 3,8 & 2 & 3 & 3 & 3 & 3 & 1 \\
\hline G & $2^{x}$ & 14 & $+^{x}$ & + & + & + & + & + & + & $-w$ & + & + & + & + & + \\
\hline TG & 2 & 23 & + & + & + & + & + & + & + & - & + & + & + & + & + \\
\hline H G & 5 & 15 & + & + & + & + & - & + & + & + & + & + & + & + & + \\
\hline VR20 & 2 & 3 & + & + & - & + & + & - & - & - & - & - & - & - & + \\
\hline VR23 & 1 & 3 & - & + & - & - & + & - & - & + & - & - & - & - & - \\
\hline OSU & 1 & 2 & - & + & + & - & + & + & + & - & + & + & + & + & - \\
\hline
\end{tabular}

zTG = 'T onda di Giffoni', W ='Willamette', VR11 =VR 11-27, B ='Barcelona', L ='Lewis', VR20 =VR 20-11, Ca= 'C asina', Cl= 'Clark', VR23 =VR23-18, H G ='H all's Giant', J = Jemtegaard \#5', $E=$ 'Ennis', OSU = OSU 228.084, G = 'Gem'.

YT he horizontal row found below the list of cultivars has the incompatibility alleles that are expressed in the pollen listed.

${ }^{x} \mathrm{~A}(+)$ indicates that the cross is compatible.

wT he (-) indicates an incompatible cross. It is preferable when identifying suitable pollinizers that the cross is compatible in both directions.

vin the vertical column, to the right of the female parent column, is the list of alleles that are expressed in the female flower.

Compatibility, the amount of viable pollen produced, and time of pollen shed must be considered when selecting a pollinizer. Diploid cultivars have two alleles: in a female flower both alleles are expressed and therefore they are codominant. The pollen may express one or both alleles, and are therefore dominant or codominant, respectively. If an allele expressed in the pollen meets the same allele in the female flower, then the cross is incompatible.

An example is a 'Barcelona' female flower with the $S_{1} S_{2}$ alleles pollinated with 'Ennis'. The pollen expresses the $\mathrm{S}$ allele. This cross is incompatible. Whereas, 'Barcelona' flowers pollinated with ' $\mathrm{H}$ all's Giant' is compatible because the alleles expressed in the pollen are $S_{5}$ and $S_{15}$. Table 1 summarizes the compatibility of a selected group of cultivars, pollinizers and advanced selections.

There are cultivars that might be compatible, however they produce a high percentage of defective pollen. 'T onda $G$ entile delle $L$ anghe', $S_{2} S_{7}$, is compatible with 'Barcelona', 'Ennis', 'C asina', and 'Willamette', but generally producesahigh percentage of nonviable pollen. Therefore, this cultivar is not recommended as a pollinizer.

$\mathrm{H}$ azelnutsaremostlydichogamous. About $90 \%$ of the cultivars studied are protandrous. Pistillate flower anthesis is temperature dependent and occurs D ecember through February, peaking in January. Four to five months separate pollination and ovule fertilization. Fertilization usually occurs between mid$M$ ay and the end of J une in $O$ regon.

Pollinizer density recommendations around the world have ranged from $3 \%$ to $30 \%$ In Oregon a $10 \%$ pollinizer density hasbeen thestandard, with a recommended distance of less than $66 \mathrm{ft}(20 \mathrm{~m})$ between the main cultivar and the nearest pollinizer. T wo or threedifferent pollinizer varietieswith different times of pollen shed are recommended (Tables 1-3).

European planting strategies usually have pollinizers placed at distances of about $60 \mathrm{ft}$ or less from the furthest tree. $\mathrm{H}$ azelnut recommendations are based on these earlier observations and use 50 to $70 \mathrm{ft}$ ( 15.2 to $21.3 \mathrm{~m}$ ) as the greatest distance from pollinizers.

The O regon hazelnut industry is presently combating the fungal disease, eastern filbert blight (Johnson et al., 1996; Pinkerton et al., 1992). Current managementrecommendationssuggest reducing the susceptible pollinizer cultivars to a density of $5 \%$ and gradually replacing those left with immune or 
more resistant genotypes. 'Barcelona' plantings with 'D aviana' pollinizers account for about $70 \%$ of O regon'shazelnut acreage. 'D aviana' is highly suscep- tible to eastern filbert blight infection. Figure 1 ranks the relative susceptibility of hazelnut cultivars used in 0 regon.

In summary, eastern filbert blight

Table 3. $\mathrm{H}$ azel nut cultivar and pollinizer combinations for possible use in the in-shell and kernel markets. Incompatibility alleles noted in parentheses.

\begin{tabular}{|c|c|c|}
\hline Market & Cultivar & Pollinizer \\
\hline In-shell & $\begin{array}{l}\text { Barcelona }\left(\mathrm{S}_{1} \mathrm{~S}_{2}\right) \\
\text { Ennis }\left(\mathbf{S}_{1} \mathrm{~S}_{11}\right)\end{array}$ & $\begin{array}{l}\text { H all's Giant }\left(\mathrm{S}_{5} \mathrm{~S}_{15}\right) \\
\text { Gem }\left(\mathrm{S}_{2} \mathrm{~S}_{14}\right) \\
\text { Lewis }\left(\mathrm{S}_{3} \mathrm{~S}_{8}\right) \\
\text { VR4-31, VR 11-27 }\left(\mathrm{S}_{1} \mathrm{~S}_{3}\right) \\
\text { VR20-11 }\left(\mathrm{S}_{2} \mathbf{S}_{3}\right) \\
\text { Casina }\left(\mathbf{S}_{10} \mathbf{S}_{21}\right) \\
\text { H all's Giant }\left(\mathbf{S}_{5} \mathbf{S}_{15}\right) \\
\text { Jemtegaard \#5 }\left(\mathrm{S}_{2} \mathbf{S}_{\mathbf{3}}\right) \\
\text { VR20-11 }\left(\mathrm{S}_{2} \mathbf{S}_{3}\right) \\
\text { VR23-18 }\left(\mathrm{S}_{1} \mathbf{S}_{\mathbf{3}}\right)\end{array}$ \\
\hline Kernel & $\begin{array}{l}\text { Willamette }\left(\mathrm{S}_{1} \mathbf{S}_{\mathbf{3}}\right) \\
\text { Lewis }\left(\mathbf{S}_{\mathbf{3}} \mathbf{S}_{\mathbf{8}}\right) \\
\text { Clark }\left(\mathbf{S}_{\mathbf{3}} \mathbf{S}_{\mathbf{8}}\right)\end{array}$ & $\begin{array}{l}\text { Tonda di Giffoni }\left(\mathbf{S}_{2} \mathrm{~S}_{23}\right) \\
\mathrm{H} \text { all's Giant }\left(\mathbf{S}_{\mathbf{5}} \mathbf{S}_{15}\right) \\
\text { Gem }\left(\mathrm{S}_{2} \mathbf{S}_{14}\right) \\
\text { Tonda di Giffoni }\left(\mathbf{S}_{\mathbf{2}} \mathrm{S}_{23}\right) \\
\text { Barcelona }\left(\mathbf{S}_{1} \mathrm{~S}_{2}\right) \\
\mathrm{H} \text { all's Giant }\left(\mathbf{S}_{5} \mathbf{S}_{15}\right) \\
\text { Gem }\left(\mathrm{S}_{2} \mathbf{S}_{14}\right) \\
\mathrm{H} \text { all's Giant }\left(\mathbf{S}_{\mathbf{5}} \mathbf{S}_{15}\right) \\
\text { Gem }\left(\mathrm{S}_{2} \mathbf{S}_{14}\right) \\
\text { Later pollinizer to bedetermined }\end{array}$ \\
\hline
\end{tabular}

Fig. 1. Relative ranking of hazelnut cultivars to eastern filbert blight susceptibility based on observational field data (Pinkerton et al., 1993; personal communication, J.W. Pscheidt and S.A. Mehlenbacher).

\begin{tabular}{lccc}
\hline Susceptible & Intermediate & Resistant & I mmune \\
\hline Ennis & Barcelona & Clark & Gasaway \\
(+++++) & $(++++)$ & $(++)$ & $(-)$ \\
Daviana & Butler & Lewis & VR 4-31 \\
(+++++) & $(++++)$ & $(++)$ & $(-)$ \\
DuChilly & H all's Giant & Gem & VR11-27 \\
(+++++) & $(++)$ & $(+)$ & $(-)$ \\
TGdL & Willamette & TdG & VR20-11 \\
(+++++) & $(+++)$ & $(+)$ & $(-)$ \\
Tonda Romana & & & VR23-18 \\
(+++++) & & & $(-)$ \\
Casina & & & \\
(+++++) & & & \\
Negret & & & \\
(+++++) & & & \\
Newberg & & & \\
(++++++) & & & \\
Dundee & & & \\
(+++++) & & & \\
\hline
\end{tabular}

TGdL = 'T onda Gentile delle L anghe'; TdG = 'T onda di G iffoni'.

$+++++=H$ ighly susceptible, long canker length, low vigor. Cultivar type $=$ 'Ennis'

$+++++=$ Susceptible, long canker length, medium vigor.

$++++=$ Intermediate susceptibility, good vigor in the presence of eastern filbert blight. C ultivar type = 'Barcelona'. $+++=$ Intermediate susceptibility, but with shorter cankers or fewer stromata than 'Barcelona', good vigor in the presence of eastern filbert blight.

$++=$ Resistant, shorter cankers and with good vigor. Cultivar type $=$ ' Clark'.

$+=\mathrm{H}$ ighly resistant, shortest cankers, can become infected but only under very high disease pressure. Cultivar type = 'Tonda di Giffoni'.

$-=I$ mmune, does not become diseased. Cultivar type = 'G asaway'.

susceptibilityaswell ashorticultural considerations of compatibility and bloom overlap with the main cultivars, is impacting pollinizer selection decisions in Oregon's hazelnut industry.

\section{Literature cited}

H ampson, C.R., A.N. Azarenko, and A. Soeldner. 1993. Pollen-stigmainteractions following compatibleand incompatiblepollinations in hazelnut. J. Amer. Soc. H ort. Sci. 118:814-819.

Johnson, K.B., S.A. M ehlenbacher, J.K. Stone, J.W. Pscheidt, and J.N . Pinkerton. 1996. Eastern filbert blight of European hazelnut: it's becoming a manageable disease. Plant D isease 80: (12)1308-1316.

M ehlenbacher, S.A. 1997a. R evised dominance hierarchy for S-allels in Corylus avellana L. Theor. A ppl. Genet. 94:360366.

M ehlenbacher, S.A. 1997b. Testing compatibility of hazelnut crosses using fluorescense microscopy. Acta H ort. 445:167-171.

M ehlenbacher, S.A. and M.M. Thompson. 1988. D ominancerelationshipsamong S-allelesin Corylusavellana L. Theor. Appl. Genet. 76:669-672.

Pinkerton, J.N, Johnson, K.B., M ehlenbacher. S.A., and Pscheidt, J.W. 1993. Susceptibility of European hazelnut clones to eastern filbert blight. Plant $D$ is. 77:261-266.

Pinkerton, J.N., K.B. Johnson, K.M. Theiling, and J.A. Griesbach. 1992. D istribution and characteristics of the eastern filbert blight epidemic in western 0 regon. Plant D is. 76:1179-1182.

Pomper, K.W., A.N. Azarenko, N Bassil, J.W. D avis, and S.A. M ehlenbacher. 1998 Identification of random amplified polymorphic DNA (RAPD) markers for selfincompatibility alleles in Corylus avellana L. Thoer. Appl. Genet. 97:479-487.

Thompson, M .M . 1979a. Growth and development of the pistillate flower and nut in 'Barcelona' filbert. J. Amer. Soc. H ort. Sci. 104(3):427-432.

Thompson, M.M. 1979b. Genetics of incompatibility in Corylusavellana L. Theor. Appl. G enet. 54:113-116.

Thompson, M.M. 1979c. Incompatibility alleles in Corylusavellana L.. Theor. Appl. Genet. 55:29-33. 